\title{
Peningkatan Kemampuan Berpikir Kritis dan Hasil Belajar Matematika dengan Model Project Based Learning (PJBL)
}

\author{
1 Dedi Kristiyanto \\ ${ }^{1}$ Prodi Pendidikan Guru Sekolah Dasar, FKIP \\ Universitas Kristen Satya Wacana, \\ Salatiga, Indonesia \\ e-mail: 292018706@student.uksw.edu ${ }^{1}$
}

\begin{abstract}
Abstrak
Penelitian tindakan kelas ini bertujuan untuk meningkatan kemampuan berpikir kritis dan hasil belajar matematika dengan model Project Based Learning (PJBL) siswa kelas IV SDN 1 Jlarem Kecamatan Gladagsari. Subjek pada penelitian ini adalah siswa kelas IV SDN 1 Jlarem dengan jumlah siswa ada 19. Metode pengumpulan data dengan menggunakan tes untuk mengetahui hasil belajar dan rubrik untuk mengetahui kemampuan berpikir kritis siswa. Data diperoleh kemudian diolah secara kuantitatif dalam bentuk rentang skor 1 hingga 4 kemudian dianalisis secara kualitatif berupa kategori pada setiap rentang yang diperoleh. Data diambil dari tiga kegiatan yaitu pra siklus, siklus I dan siklus II. Data kemampuan berpikir kritis yang diperoleh siswa pra siklus sebesar $10 \%$, siklus I sebesar $63,16 \%$ dan siklus II sebesar $84,21 \%$. Serta diperoleh data hasil belajar siswa pra siklus sebesar $36,84 \%$, siklus I sebesar $84,21 \%$ dan siklus II sebesar 89,47\%. Jadi, penerapan model Project Based Learning (PJBL) efektif dalam meningkatkan kemampuan berpikir kritis siswa, serta dapat meningkatkan hasil belajar matematika kelas IV SDN 1 Jlarem
\end{abstract}

Kata Kunci: (pbl), berpikir kritis, hasil belajar.

\begin{abstract}
This class action research aims to improve critical thinking skills and mathematics learning outcomes with the Project Based Learning (PJBL) model of grade IV students at SDN 1 Jlarem, Gladagsari District. This type of research is PTK. The subjects in this study were fourth grade students at SDN 1 Jlarem with 19 students. The data collection method was using tests to find out the learning outcomes and rubrics to determine students' critical thinking skills. The data obtained is then processed quantitatively in the form of a range of scores 1 to 4 then analyzed qualitatively in the form of a category in each range obtained. The data is taken from three activities namely pre cycle, cycle I and cycle II. Critical thinking skills data obtained by pre-cycle students was $10 \%$, first cycle was $63.16 \%$ and second cycle was $84.21 \%$. And the data obtained from pre-cycle student learning outcomes of $36.84 \%$, the first cycle of $84.21 \%$ and the second cycle of $89.47 \%$. From the results of this study it can be concluded that the application of the Project Based Learning (PJBL) model is effective in improving students' critical thinking skills, and can improve mathematics learning outcomes of grade IV SDN 1 Jlarem.
\end{abstract}

Keywords: project based learning, critical thinking, learning outcomes.

\footnotetext{
*Corresponding author.

Received 20 January 2020, Accepted 20 March 2020; Available online 5 Appril 2020 (C) 2020 MI All Rights Reserved
} 


\section{Pendahuluan}

Peraturan Menteri Pendidikan dan Kebudayaan No. 37 Tahun 2018 menegaskan bahwa kurikulum 2013 untuk sekolah dasar sudah diberlakukan pembelajaran tematik mulai dari kelas 1 sampai kelas 6 , kecuali pelajaran matematika, penerapan pembelajaran matematika secara terpisah ini di mulai pada kelas IV, V dan VI. Mata pelajaran matematika perlu dipelajari kepada siswa mulai dari sekolah dasar untuk membekali peserta didik dengan kemampuan berpikir logis, analitis, sistematis, kritis, dan kreatif, serta kemampuan bekerjasama. Kompetensi tersebut diperlukan agar peserta didik dapat memiliki kemampuan memperoleh, mengelola, dan memanfaatkan informasi untuk bertahan hidup pada keadaan yang selalu berubah, tidak pasti, dan kompetitif. (Permendikbud No. 21 Tahun 2016)

Belajar adalah apa yang menyebabkan perkembangan berpikir tingkat tinggi. Hal ini sesuai dengan amanat pola pembelajaran pada kurikulum 2013 yang salah satu pola pikirnya yaitu pembelajaran untuk melatih berpikir kritis. Sedangkan salah satu tujuan utama sekolah adalah meningkatkan kemampuan siswa untuk berpikir kritis, membuat keputusan rasional tentang apa yang diyakini. Untuk itu, perlu membelajarkan siswa untuk berpikir kritis. (Permendikbud 58 Tahun 2014). Akan tetapi menurut hasil studi The Third International Mathemathical Science Study Repeat (TIMSS-R) tahun 2015, kemampuan matematika siswa di Indonesia masih sangat rendah. Hasil studi TIMSS-R menyebutkan bahwa dari 49 negara Indonesia berada diperingkat 44.

Dengan demikian perlu dalam sebuah pelajaran menggunakan model pembelajaran yang dapat menyelesaikan masalah tersebut dimana model pembelajaran menekankan pada perkembangan berpikir tingkat tinggi atau berpikir kritis. Salah satu model pembelajaran yang lebih memperdayakan kepada keaktifan, kreatifitas dan inovatif serta pola pikir kritis yakni dengan model belajar Project Based Learning (PJBL). Istarani (2011: 156) mengemukakan pendapatnya bahwa Pembelajaran Berbasis Proyek (Project Based Learning) yaitu sebuah model atau pendekatan pembelajaran yang inovatif dan menekankan untuk belajar secara kontekstual melalui kegiatan-kegiatan yang kompleks.

Pada kelas IV SDN 1 Jlarem memiliki beberapa masalah yang ditemukan di antaranya siswa kurang aktif dalam proses pembelajaran juga ada yang masih takut untuk bertanya dan berpendapat. Sehingga proses belajar mengajar yang seharusnya berpusat pada siswa didominasi oleh guru yang berperan sebagai penyalur ilmu pengetahuan. Belum adanya pembelajaran penugasan proyek yang menekankan pada suatu kegiatan penelitian berdasarkan tema atau topik yang sudah ditentukan dalam pembelajaran. Sehingga situasi siswa disana masih banyak siswa yang kurang antusias dalam menerima pembelajaran karena guru juga masih kurang menerapkan model-model pembelajaran yang menekankan keaktifan siswa yang sekaligus membuat anak kurang kritis dalam menerima dan menalar materi yang diberikan yang dimana itu berdampak pada rendahnya perolehan nilai siswa dalam pelajaran. Tak sedikit siswa memperoleh nilai yang dibawah KKM yaitu 65. Dari hasil observasi siswa yang memperoleh nilai tuntas mencapai presentase $40 \%$, sedangkan siswa lainnya memperoleh nilai dibawah KKM yaitu mencapai presentase $60 \%$.

Model dalam pembelajaran yang inovatif harus dipilih dan diterapkan guru untuk proses belajar yang lebih baik. Istarani (2011: 156) mengemukakan pendapatnya bahwa Pembelajaran Berbasis Proyek (Project Based Learning) yaitu sebuah model atau pendekatan pembelajaran yang inovatif dan menekankan untuk belajar secara kontekstual melalui kegiatan-kegiatan yang kompleks. Yetkiner,Z.E, at all. (2008), mendapati sebuah kesimpulan bahwa Project Based Learning memperlihatkan adanya bukti bahwa keefekifan dalam peningkatan pada hasil belajar siswa juga menambah kemampuan pemecahan siswa, adanya peningkatan siswa dalam memahami pelajaran dan peningkatan sikap yang baik pada matematika serta peningkatan dalam bekerjasama. Dengan begitu dapat disimpulkan bahwa pembelajaran siswa dapat mengasah serta mengeksplor setiap materi yang diterima dengan kognitifnya yang sebelumnya 
terlatih berpikir kritis dengan model pembelajaran ini Project Based Learning (PJBL) dan memungkinkan setiap siswa terlibat aktif dan kritis dalam proses belajarnya.

\section{Metode}

Jenis penelitian ini adalah Penelitian Tindakan Kelas (PTK). Kemmis dan Carr (Kasbolah, 1999: 13), mengemukakan bahwa "penelitian tindakan kelas merupakan suatu bentuk penelitian yang bersifat reflektif yang dilakukan oleh pelaku didalam masyarakat sosial dan bertujuan untuk memperbaiki pekerjaannya, memahami pekerjaannya, serta memahami situasi dimana pekerjaan itu dilakukan". Langkah-langkah menurut model Kemmis \& Mc.Taggart (Arikunto, 2010: 137), digambarkan sebagai suatu proses yang dinamis, meliputi 4 aspek yaitu 1) Perencanaan, sebelum mengadakan penelitian peneliti menyusun rumusan masalah, tujuan dan membuat rencana tindakan, termasuk didalamnya instrumen penelitian dan perangkat pembelajaran; 2) Tindakan, meliputi tindakan yang dilakukan oleh peneliti sebagai upaya membangun pemahaman konsep siswa; 3) Observasi, mengamati hasil atau dampak dari diterapkannya model pembelajaran Project Based Learning (PJBL). Observasi dibagi dalam dua siklus dimana masing-masing siklus dikenai perlakuan yang sama (alur kegiatan yang sama) dan membahas satu sub pokok bahasan yang diakhiri dengan tes di akhir pembelajaran; 4) Refleksi, peneliti mengkaji, melihat dan mempertimbangkan hasil dari tindakan yang dilakukan berdasarkan observasi. Berdasarkan hasil refleksi tersebut kemudian dapat diputuskan apakah dilanjutkan pada siklus berikutnya ataukah tidak. Jadi dapat disimpulkan bahwa Penelitian Tindakan Kelas adalah penelitian yang bertujuan untuk melakukan tindakan perbaikan, peningkatan dan juga melakukan suatu perubahan kearah yang lebih baik dari sebelumnya sebagai upaya pemecahan masalah yang dihadapi, terutama ditunjukan pada kegiatan pembelajaran atau proses belajar-mengajar di kelas untuk meningkatkan kemampuan berpikir kritis siswa dan hasil belajar. Subjek penelitian adalah siswa kelas IV SDN 1 Jlarem Kec. Gladagsari.

Teknik pengumpulan data variabel bebas (X) yaitu pengumpulan data pada model pembelajaran Project Based Learning (PJBL) ini dilakukan dengan menggunakan teknik nontes yaitu observasi. Observasi akan dilakukan terhadap aktivitas guru dan siswa dalam menerapkan model pembelajaran Project Based Learning (PJBL).

Teknik pengumpulan data variabel terikat $(Y)$ yaitu pengumpulan data berpikir kritis dilakukan dengan menggunakan teknik tes. Tes akan dilakukan untuk mengukur penguasaan siswa terhadap materi yang telah disampaikan setelah penerapan model pembelajaran Project Based Learning (PJBL). Tes tersebut digunakan untuk mengukur kognitif dan berpikir kritis siswa dalam menyelesaikan soal.

\section{Hasil dan Pembahasan.}

Untuk melihat perkembangan kelas bisa dilihat suatu perbedaan hasil perolehan data dari siklus I dan siklus II menurut keterlaksanaan pembelajaran yang tercapai. Model pembelajaran pada dasarnya adalah suatu bentuk pembelajaran yang tergambar dari awal hingga akhir pembelajaran yang disajikan secara khas oleh guru. Model pembelajaran dengan kata lain merupakan bungkus atau bingkai dari penerapan suatu pendekatan, metode, dan teknik pembelajaran (Komalasari, 2013: 57).

Berikut hasil perolehan data yang sebagaimana rancangan tindakan pembelajaran diadaptasi dengan penerapan model pembelajaran Project Based Learning (PJBL) dari mulai siklus I sampai siklus II. 


\section{Tabel 01}

Hasil observasi aktivitas guru siklus I

\begin{tabular}{|c|c|c|c|c|}
\hline \multirow{2}{*}{ No } & \multirow{2}{*}{ Kegiata Belajar } & \multirow{2}{*}{ Aspek yang diamati } & \multicolumn{2}{|c|}{ Tindakan } \\
\hline & & & Ya & Tidak \\
\hline 1 & & $\begin{array}{l}\text { Mempersiapkan materi dan media yang akan } \\
\text { digunakan dalam mengajar }\end{array}$ & $\sqrt{ }$ & \\
\hline 2 & & Memberi salam pada siswa & $\sqrt{ }$ & \\
\hline 3 & Pendahuluan & $\begin{array}{l}\text { Berdoa sebelum mengawali kegiatan belajar } \\
\text { mengajar bersama siswa }\end{array}$ & & $\sqrt{ }$ \\
\hline 4 & & Menanyakan kehadiran siswa dan absensi & $\sqrt{ }$ & \\
\hline 5 & & Melakukan apersepsi & $\sqrt{ }$ & \\
\hline 6 & & Menyampaikan tujuan pembelajaran & $\sqrt{ }$ & \\
\hline 7 & & Melakukan pertanyaan mendasar & & $\sqrt{ }$ \\
\hline 8 & & $\begin{array}{l}\text { Memberikan sebuah kartu berbentuk bangun } \\
\text { datar kepada siswa untuk dipilih secara acak }\end{array}$ & $\sqrt{ }$ & \\
\hline 9 & & $\begin{array}{l}\text { Mengintruksi siswa untuk membuat kelompok } \\
\text { sesuai kartu dengan bentuk yang sama }\end{array}$ & $\sqrt{ }$ & \\
\hline 10 & & Menjelaskan materi tentang bangun datar & $\sqrt{ }$ & \\
\hline 11 & & $\begin{array}{l}\text { Membagikan kartu berbentuk bangun } \\
\text { persegi, persegi panjang dan segitiga }\end{array}$ & $\sqrt{ }$ & \\
\hline 12 & & $\begin{array}{l}\text { Menjelaskan materi cara mencari dan } \\
\text { menentukan keliling dan luas bangun }\end{array}$ & $\sqrt{ }$ & \\
\hline 13 & Kegiatan Inti & $\begin{array}{l}\text { Membagikan tugas kelompok dan sebuah } \\
\text { puzzle tangram pada masing-masing } \\
\text { kelompok }\end{array}$ & $\sqrt{ }$ & \\
\hline 14 & & $\begin{array}{l}\text { Memberitahukan siswa hasil kelompok akan } \\
\text { dipresentasikan kedepan oleh wakil } \\
\text { kelompok }\end{array}$ & $\sqrt{ }$ & \\
\hline 15 & & Memonitor hasil kerja siswa & $\sqrt{ }$ & \\
\hline 16 & & $\begin{array}{l}\text { Melakukan tunjuk kelompok untuk presentasi } \\
\text { kedepan }\end{array}$ & $\sqrt{ }$ & \\
\hline 17 & & $\begin{array}{l}\text { Memberikan penilaian sebagai umpan balik } \\
\text { pada siswa }\end{array}$ & $\sqrt{ }$ & \\
\hline
\end{tabular}

\begin{tabular}{llll}
\hline 18 & Penutup & $\begin{array}{l}\text { Memberikan kesempatan untuk bertanya } \\
\text { tentang hal yang belum dimengerti } \\
\text { Membuat kesimpulan pembelajaran yang }\end{array}$ & $\sqrt{ }$ \\
& $\begin{array}{l}\text { telah dilakukan bersama siswa } \\
\text { Melakukan refleksi: "materi apa yang telah } \\
\text { dipelajari" "materi apa yang belum dipahami” } \\
\text { "bagaimana perasaan selama pembelajaran" } \\
\text { Mengintruksi siswa untuk merapikan } \\
\text { peralatan belajar kemudian salam } \\
\text { istirahat/berdoa sesuai agama dan } \\
\text { kepercayaan masing-masing }\end{array}$ & $\sqrt{ }$ \\
& & & \\
& & $\mathbf{1 9}$ & $\mathbf{2}$ \\
\hline Jumlah & & $\mathbf{9 0 \%}$ & $\mathbf{1 0 \%}$ \\
\hline Persentase & & & \\
\hline
\end{tabular}

Dari tabel 01 dapat dilihat bahwa kegiatan pembelajaran pada siklus I dengan menggunakan model pembelajaran Project Based Learning (PJBL) sudah tercapai meskipun 
masih ada beberapa kegiatan yang belum dilaksanakan. Hal tersebut menunjukan keterlaksanaan hanya $90 \%$ dan yang belum terlaksana $10 \%$.

Tabel 02

Hasil observasi aktivitas siswa siklus I

\begin{tabular}{|c|c|c|c|c|}
\hline \multirow[t]{2}{*}{ No } & \multirow{2}{*}{$\begin{array}{l}\text { Kegiatan } \\
\text { belajar }\end{array}$} & \multirow[t]{2}{*}{ Aspek yang diamati } & \multicolumn{2}{|c|}{ Tindakan } \\
\hline & & & Ya & Tidak \\
\hline 1 & Pendahuluan & $\begin{array}{l}\text { Mempersiapkan materi dan media yang akan } \\
\text { digunakan dalam mengajar }\end{array}$ & $\sqrt{ }$ & \\
\hline 2 & & Memberi salam & $\sqrt{ }$ & \\
\hline 3 & & $\begin{array}{l}\text { Berdoa sebelum mengawali kegiatan belajar } \\
\text { mengajar bersama siswa }\end{array}$ & & $\sqrt{ }$ \\
\hline 4 & & Melakukan absensi & $\sqrt{ }$ & \\
\hline 5 & & Melakukan apersepsi & $\sqrt{ }$ & \\
\hline 6 & & Mendengarkan tujuan pembelajaran & $\sqrt{ }$ & \\
\hline 7 & Kegiatan Inti & Menjawab pertanyaan dari guru & & $\sqrt{ }$ \\
\hline 8 & & Memilih kartu berbentuk bangun datar secara acak & $\sqrt{ }$ & \\
\hline 9 & & $\begin{array}{l}\text { Membuat kelompok sesuai kartu dengan bentuk } \\
\text { yang sama yang sudah diperoleh }\end{array}$ & $\sqrt{ }$ & \\
\hline 10 & & $\begin{array}{l}\text { Mendengarkan dan memahami materi tentang } \\
\text { bangun datar yang disampaikan oleh guru }\end{array}$ & $\sqrt{ }$ & \\
\hline 11 & & $\begin{array}{l}\text { Menerima kartu kartu berbentuk bangun persegi, } \\
\text { persegi panjang dan segitiga dari guru }\end{array}$ & $\sqrt{ }$ & \\
\hline 12 & & $\begin{array}{l}\text { Mendengarkan dan memahami materi tentang cara } \\
\text { mencari dan menentukan keliling dan luas bangun }\end{array}$ & $\sqrt{ }$ & \\
\hline 13 & & $\begin{array}{l}\text { Menerima tugas kelompok dan sebuah puzzle } \\
\text { tangram dari guru }\end{array}$ & $\sqrt{ }$ & \\
\hline 14 & & $\begin{array}{l}\text { Mendengarkan intruksi guru dalam hasil kelompok } \\
\text { akan dipresentasikan kedepan oleh wakil } \\
\text { kelompok }\end{array}$ & $\sqrt{ }$ & \\
\hline 15 & & $\begin{array}{l}\text { Berdiskusi kelompok untuk mengerjakan tugas } \\
\text { kelompok dan menyelesaikan puzzle tangram }\end{array}$ & $\sqrt{ }$ & \\
\hline 16 & & $\begin{array}{l}\text { Wakil kelompok maju kedepan untuk } \\
\text { mempresentasikan hasil kerja kelompok }\end{array}$ & $\sqrt{ }$ & \\
\hline 17 & & Mendapatkan penilaian dari guru & $\sqrt{ }$ & \\
\hline 18 & Penutup & Bertanya tentang materi yang belum dimengerti & & $\sqrt{ }$ \\
\hline 19 & & Menyimpulkan pembelajaran yang telah diterima & $\sqrt{ }$ & \\
\hline 20 & & $\begin{array}{l}\text { Melakukan refleksi: "materi apa yang telah } \\
\text { dipelajari" "materi apa yang belum dipahami" } \\
\text { "bagaimana perasaan selama pembelajaran" }\end{array}$ & $\sqrt{ }$ & \\
\hline 21 & & $\begin{array}{l}\text { Merapikan peralatan belajar kemudian salam } \\
\text { istirahat/berdoa sesuai agama dan kepercayaan } \\
\text { masing-masing }\end{array}$ & $\sqrt{ }$ & \\
\hline Jum & & & 18 & 3 \\
\hline Pers & entase & & $86 \%$ & $14 \%$ \\
\hline
\end{tabular}


Dari tabel 02 diatas siswa sudah melaksanakan kegiatan pembelajaran dengan menerapkan model pembelajaran Project Based Learning (PJBL) dengan baik. Hal ini terbukti dengan presentase keterlaksanaan kegiatan siswa sebesar $86 \%$.

Selanjutnya pengumpulan data aktivitas guru dan aktivitas siswa siklus II:

\section{Tabel 03}

Hasil observasi aktivitas guru siklus II

\begin{tabular}{|c|c|c|c|}
\hline \multirow[t]{2}{*}{ No } & \multirow[t]{2}{*}{ Kegiata Belajar } & \multirow[t]{2}{*}{ Aspek yang diamati } & Tindakan \\
\hline & & & Ya Tidak \\
\hline 1 & Pendahuluan & $\begin{array}{l}\text { Mempersiapkan materi dan media yang } \\
\text { akan digunakan dalam mengajar }\end{array}$ & $\sqrt{1}$ \\
\hline 2 & & Memberi salam pada siswa & $\sqrt{ }$ \\
\hline 3 & & $\begin{array}{l}\text { Berdoa sebelum mengawali kegiatan } \\
\text { belajar mengajar bersama siswa }\end{array}$ & $\sqrt{ }$ \\
\hline 4 & & $\begin{array}{l}\text { Menanyakan kehadiran siswa dan } \\
\text { absensi }\end{array}$ & $\sqrt{ }$ \\
\hline 5 & & Melakukan apersepsi & $\sqrt{ }$ \\
\hline 6 & & Menyampaikan tujuan pembelajaran & $\sqrt{ }$ \\
\hline 7 & Kegiatan Inti & Melakukan pertanyaan mendasar & $\sqrt{ }$ \\
\hline 8 & & $\begin{array}{l}\text { Memberikan sebuah kartu berbentuk } \\
\text { bangun datar kepada siswa untuk dipilih } \\
\text { secara acak }\end{array}$ & $\sqrt{ }$ \\
\hline 9 & & $\begin{array}{l}\text { Mengintruksi siswa untuk membuat } \\
\text { kelompok sesuai kartu dengan bentuk } \\
\text { yang sama }\end{array}$ & $\sqrt{ }$ \\
\hline 10 & & $\begin{array}{l}\text { Menjelaskan materi tentang bangun } \\
\text { datar }\end{array}$ & $\sqrt{ }$ \\
\hline 11 & & $\begin{array}{l}\text { Membagikan kartu berbentuk bangun } \\
\text { persegi, persegi panjang dan segitiga }\end{array}$ & $\sqrt{ }$ \\
\hline 12 & & $\begin{array}{l}\text { Menjelaskan materi cara mencari dan } \\
\text { menentukan keliling dan luas bangun }\end{array}$ & $\sqrt{ }$ \\
\hline 13 & & $\begin{array}{l}\text { Membagikan tugas kelompok dan } \\
\text { sebuah puzzle tangram pada masing- } \\
\text { masing kelompok }\end{array}$ & $\sqrt{ }$ \\
\hline 14 & & $\begin{array}{l}\text { Memberitahukan siswa hasil kelompok } \\
\text { akan dipresentasikan kedepan oleh } \\
\text { wakil kelompok }\end{array}$ & $\sqrt{ }$ \\
\hline 15 & & Memonitor hasil kerja siswa & $\sqrt{ }$ \\
\hline 16 & & $\begin{array}{l}\text { Melakukan tunjuk kelompok untuk } \\
\text { presentasi kedepan }\end{array}$ & $\sqrt{ }$ \\
\hline 17 & & $\begin{array}{l}\text { Memberikan penilaian sebagai umpan } \\
\text { balik pada siswa }\end{array}$ & $\sqrt{ }$ \\
\hline 18 & Penutup & $\begin{array}{l}\text { Memberikan kesempatan untuk } \\
\text { bertanya tentang hal yang belum } \\
\text { dimengerti }\end{array}$ & $\sqrt{ }$ \\
\hline 19 & & $\begin{array}{l}\text { Membuat kesimpulan pembelajaran } \\
\text { yang telah dilakukan bersama siswa }\end{array}$ & $\sqrt{ }$ \\
\hline 20 & & $\begin{array}{l}\text { Melakukan refleksi: "materi apa yang } \\
\text { telah dipelajari" "materi apa yang belum } \\
\text { dipahami" "bagaimana perasaan selama } \\
\text { pembelajaran" }\end{array}$ & $\sqrt{ }$ \\
\hline
\end{tabular}



kepercayaan masing-masing

\begin{tabular}{lcc}
\hline Jumlah & 21 & 0 \\
\hline Persentase & $100 \%$ & $0 \%$ \\
\hline
\end{tabular}

Dari tabel 4.14 di atas dapat dilihat bahwa guru telah sepenuhnya melaksanakan kegiatan pembelajaran dengan menerapkan model pembelajaran Project Based Learning (PJBL) dengan sangat baik. Hal tersebut terbukti bahwa keterlaksanakan kegiatan siklus II tidak mengalami kendala sehingga pelaksanakan berjalan dengan lancar. Hasil yang diperoleh pada lembar observasi menunjukkan bahwa semua kegiatan telah dilakukan dengan persentase $100 \%$, dan kegiatan yang tidak dilakukan terdapat persentase $0 \%$.

Tebel 04

Hasil observasi aktivitas siswa siklus II

\begin{tabular}{|c|c|c|c|}
\hline \multirow{2}{*}{ No } & \multirow{2}{*}{ Kegiatan belajar } & \multirow{2}{*}{ Aspek yang diamati } & Tindakan \\
\hline & & & Ya Tidak \\
\hline 1 & & $\begin{array}{l}\text { Mempersiapkan materi dan media yang } \\
\text { akan digunakan dalam mengajar }\end{array}$ & $\sqrt{ }$ \\
\hline 2 & & Memberi salam & $\sqrt{ }$ \\
\hline 3 & Pendahuluan & $\begin{array}{l}\text { Berdoa sebelum mengawali kegiatan } \\
\text { belajar mengaiar bersama siswa }\end{array}$ & $\sqrt{ }$ \\
\hline 4 & & Melakukan absensi & $\sqrt{ }$ \\
\hline 5 & & Melakukan apersepsi & $\sqrt{ }$ \\
\hline 6 & & Mendengarkan tujuan pembelajaran & $\sqrt{ }$ \\
\hline 7 & & Menjawab pertanyaan dari guru & $\sqrt{ }$ \\
\hline 8 & & $\begin{array}{l}\text { Memilih kartu berbentuk bangun datar } \\
\text { secara acak }\end{array}$ & $\sqrt{ }$ \\
\hline 9 & & $\begin{array}{l}\text { Membuat kelompok sesuai kartu dengan } \\
\text { bentuk yang sama yang sudah diperoleh }\end{array}$ & $\sqrt{ }$ \\
\hline 10 & & $\begin{array}{l}\text { Mendengarkan dan memahami materi } \\
\text { tentang bangun datar yang disampaikan } \\
\text { oleh guru }\end{array}$ & $\sqrt{ }$ \\
\hline 11 & & $\begin{array}{l}\text { Menerima kartu kartu berbentuk bangun } \\
\text { persegi, persegi panjang dan segitiga } \\
\text { dari guru }\end{array}$ & $\sqrt{ }$ \\
\hline 12 & Kegiatan Inti & $\begin{array}{l}\text { Mendengarkan dan memahami materi } \\
\text { tentang cara mencari dan menentukan } \\
\text { keliling dan luas bangun }\end{array}$ & $\sqrt{ }$ \\
\hline 13 & & $\begin{array}{l}\text { Menerima tugas kelompok dan sebuah } \\
\text { puzzle tangram dari guru }\end{array}$ & $\sqrt{ }$ \\
\hline 14 & & $\begin{array}{l}\text { Mendengarkan intruksi guru dalam hasil } \\
\text { kelompok akan dipresentasikan kedepan } \\
\text { oleh wakil kelompok }\end{array}$ & $\sqrt{ }$ \\
\hline 15 & & $\begin{array}{l}\text { Berdiskusi kelompok untuk mengerjakan } \\
\text { tugas kelompok dan menyelesaikan } \\
\text { puzzle tangram }\end{array}$ & $\sqrt{ }$ \\
\hline 16 & & $\begin{array}{l}\text { Wakil kelompok maju kedepan untuk } \\
\text { mempresentasikan hasil kerja kelompok }\end{array}$ & $\sqrt{ }$ \\
\hline
\end{tabular}




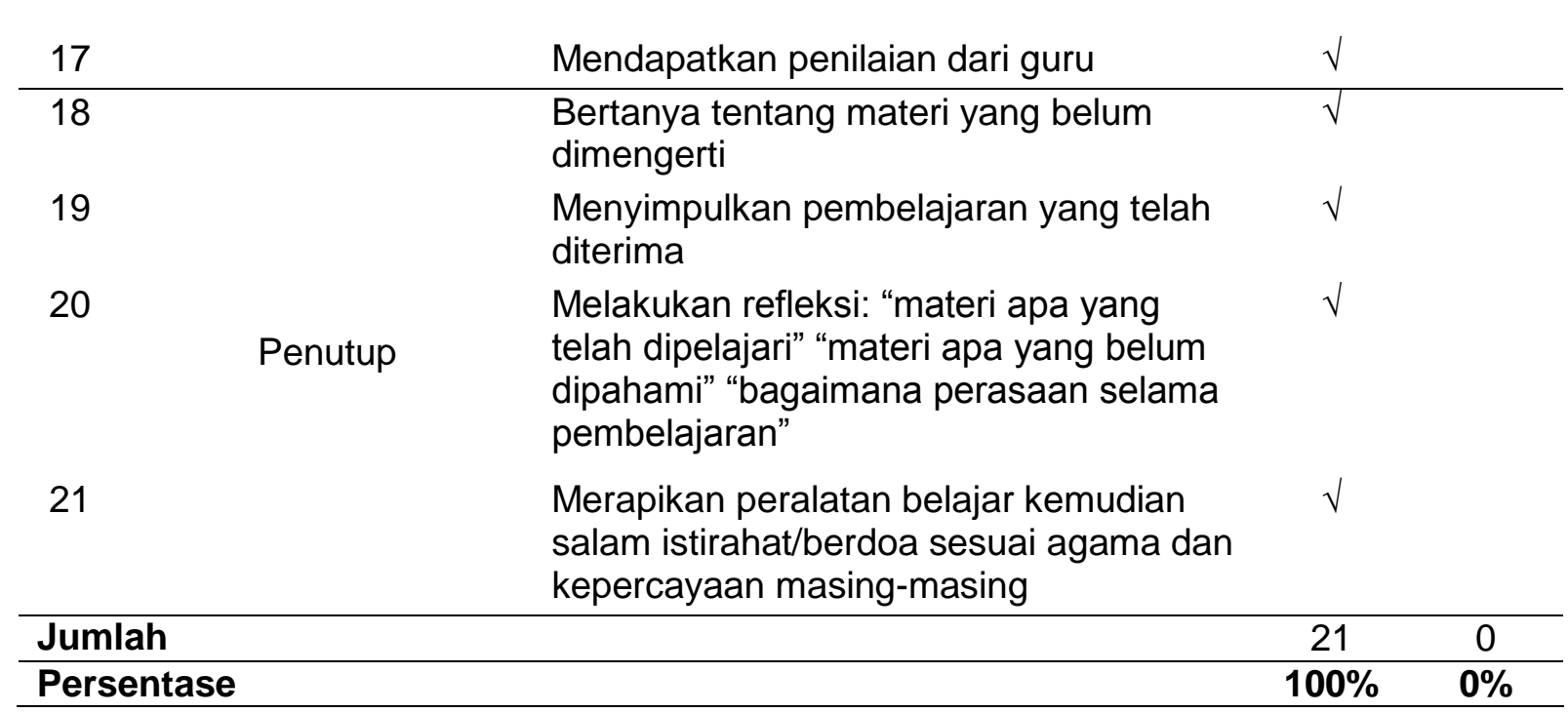

Dari tabel 04 dapat kita lihat bahwa seluruh siswa sudah melaksanakan seluruh kegiatan pembelajaran dengan menerapkan model pembelajaran Project Based Learning (PJBL) yang telah dilakukan pada kegiatan siklus II. Hal ini terbukti dengan persentase $100 \%$ seluruh kegiatan dilakukan dan persentase $0 \%$ untuk kegiatan yang tidak dilakukan. Dengan hasil yang telah diperoleh menjelaskan bahwa model pembelajaran Project Based Learning (PJBL) dapat diterima dan diterapkan oleh siswa, sehingga model ini bisa diterapkan untuk pembelajaran khususnya mata pelajaran Matematika.

Hasil pengumpulan data untuk variabel terikat $(\mathrm{Y})$ diperoleh dari hasil tes siswa untuk mengetahui kemampuan berpikir kritis siswa dan hasil belajar siswa setelah diterapkannya model Project Based Learning (PJBL) dari pra siklus, siklus I dan siklus II. Hasil data yang diperoleh dapat dilihat melalui perbandingan data pada tabel berikut:

\section{Tabel 05}

Perbandingan kemampuan berpikir kritis matematika pra siklus, siklus I dan siklus II

\begin{tabular}{ccccccccc}
\hline No. & \multicolumn{2}{c}{ Kriteria Berpikir Kritis } & \multicolumn{2}{c}{ Pra Siklus } & \multicolumn{2}{c}{ Siklus I } & \multicolumn{2}{c}{ Siklus II } \\
\cline { 2 - 8 } & Interval Nilai & Kategori & $\mathbf{f}$ & $\%$ & $\mathbf{f}$ & $\%$ & $\mathbf{f}$ & $\%$ \\
\hline 1 & $16-20$ & Sangat Bagus & 2 & $10 \%$ & 12 & $63,16 \%$ & 16 & $84,21 \%$ \\
2 & $11-15$ & Bagus & 7 & $37 \%$ & 7 & $36,84 \%$ & 3 & $15,79 \%$ \\
3 & $6-10$ & Cukup & 6 & $32 \%$ & - & - & - & - \\
4 & $1-5$ & Kurang Bagus & 4 & $21 \%$ & - & - & - & - \\
\hline & Jumlah & & 19 & $100 \%$ & 19 & $100 \%$ & 19 & $100 \%$
\end{tabular}

Berdasarkan tabel diatas dapat dilihat perbandingan kemampuan berpikir kritis siswa pada pembelajaran matematika dari mulai pra siklus, siklus I dan siklus II. Hasil dari tabel perbandingan menunjukan bahwa pada pra siklus terdapat 2 siswa dengan presentase $10 \%$ dalam kategori sangat bagus, 7 siswa dengan presentase 37\% dalam kategori bagus, 6 siswa dengan presentase $32 \%$ dalam kategori cukup dan sisanya sebanyak 4 siswa dengan presentase $21 \%$ dalam kategori kurang bagus. Setelah dilakukan kegiatan pembelajaran dengan diterapkannya model pembelajaran Project Based Learning (PJBL) kemampuan berpikir kritis siswa mengalami peningkatan. Hal tersebut dapat dilihat pada siklus I terdapat 12 
siswa dengan presentase $63,16 \%$ dalam kategori sangat bagus dan sisanya 7 siswa dengan presentase $36,84 \%$ dalam kategori bagus. Kemudian setelah dilakukan kegiatan siklus II, kemampuan berpikir kritis siswa meningkat menjadi 16 siswa dengan presentase $84,21 \%$ dalam kategori sangat bagus dan sisanya 3 siswa dengan presentase $15,79 \%$ dalam kategori bagus.

Tujuan dalam penelitian ini yaitu untuk menjelaskan penerapan langkah-langkah model pembelajaran Project Based Learning (PJBL) dalam meningkatkan kemampuan berpikir kritis dan hasil belajar matematika siswa kelas IV SDN 1 Jlarem.

Sebelum dilaksanakan penelitian, penelitian melakukan kegiatan observasi kegiatan pembelajaran dan lanjutkan wawancara terhadap guru untuk memperoleh permasalahan dalam kegiatan pembelajaran matematika siswa kelas IV SDN Jlarem yang belum menerapkan model pembelajaran Project Based Learning (PJBL). Kegiatan observasi dilakukan pada proses pembelajaran bertujuan untuk memperoleh data kemampuan berpikir kritis siswa. Sedangkan kegiatan wawancara kepada guru dilakukan bertujuan untuk memperoleh data hasil belajar siswa. Peniliti melakukan wawancara terhadap nilai ulangan matematika dan mendapatkan hasil bahwa banyak siswa yang belum tuntas atau belum mencapai KKM $(\geq 65)$. Kemudian dilanjutkan dengan observasi terhadap pembelajaran untuk mendapatkan data kemampuan berpikir kritis siswa dan ternyata masih banyak siswa yang tergolong dalam berpikir kritis rendah. Hasil observasi terhadap kemampuan berpikir kritis siswa pada pra siklus dapat dilihat bahwa dari jumlah 19 siswa terdapat 2 siswa kategori sangat bagus dengan persentase 10\%, 7 siswa kategori bagus dengan persentase 37\%, 6 siswa kategori cukup dengan persentase $32 \%$, dan 4 siswa kategori kurang baik dengan persentase $21 \%$.

Penerapan model pembelajaran Project Based Learning (PJBL) tidak hanya meningkatkan hasil belajar saja tetapi juga meningkatkan kemampuan berpikir kritis siswa pada mata pelajaran matematika. Hal ini dapat dilihat dari peningkatan yang telah terjadi dari kegiatan pra siklus ke pembelajaran siklus I. Pada pra siklus diperoleh data kemampuan berpikir kritis siswa sebesar $51,31 \%$ dan kemudian diterapkan model pembelajaran Project Based Learning (PJBL) pada siklus I meningkat menjadi 78,42\%. Namun masih terdapat indikator berpikir kritis siswa yang masih belum tercapai indikator keberhasilan yang diharapkan, maka dilakukan kegiatan siklus II dengan menerapkan model pembelajaran Project Based Learning (PJBL) untuk mengukur peningkatan berpikir kritis siswa. Dari hasil observasi yang diperoleh data yang memperlihatkan terjadinya peningkatan yang terjadi pada siklus I sebesar $78,42 \%$, pada siklus II meningkat menjadi $84,21 \%$. Hal ini terbukti bahwa menggunakan model pembelajaran Project Based Learning (PJBL) dapat meningkatkan berpikir kritis siswa dalam mencari solusi pemecahan masalah.

\section{Simpulan dan Saran}

Berdasarkan hasil penelitian dan pembahasan yang telah diuraikan sebelumnya, maka dapat disimpulkan bahwa terdapat perbedaan kemampuan berpikir kritis antara siswa yang dibelajarkan menggunakan model Project Based Learning (PJBL) dengan siswa yang dibelajarkan menggunakan model konvensional. Jadi model Project Based Learning (PJBL) efektif dalam meningkatkan kemampuan berpikir kritis dan hasil belajar siswa.

Berdasarkan simpulan tersebut, dapat disarankan beberapa hal, antara lain: 1) Bagi sekolah, Dibanding dengan model konvensional dalam pembelajaran akan lebih efektif dalam peningkatan kemampuan berpikir kritis siswa dengan menggunakan model Project Based Learning (PJBL) sehingga membantu mengurangi masalah dalam kelas; 2) Bagi siswa, Cara berpikir siswa dalam pembuatan produk bila terkontruksi dengan baik dan bisa menyelesaikan suatu produk tertentu akan membuat pola pikir siswa lebih terangsang untuk kreatif dan kritis dalam pemecahan masalah sehingga mereka bisa menemukan berbagai solusi untuk diterapkan; 3) Bagi Guru, Hasil kajian ini didapati bahwa dengan mengunakan model pembelajaran Project Based Learning (PJBL) siswa lebih aktif dalam proses belajar karena 
dasar dari model ini adalah membuat suatu produk dari suatu benda yang sesuai dengan karakter siswa yang masih suka bermain dan keingintahuannya yang besar. Siswa juga senang dalam penghitungan suatu produk yang mereka buat membuat siswa lebih tertarik dan terkonsentrasi dalam pemecahan masalah sehingga akan memudahkan guru dalam proses belajar matematika.

\section{Daftar Pustaka}

Ainamulyana.blogspot.com. (21 Agustus 2018). Permendikbud Nomor 21 Tahun 2016 tentang Standar Isi Pendidikan Dasar dan Menengah. < https://ainamulyana.blogspot.com/2016/07/download-permendikbud-no-21-tahun2016.html>

Yetkiner,Z.E., Anderoglu, H., \& Capraro, R. M. (2008). Research Summary: Project-based learning in midlle grades mathematics.

Ruseffendi, ET. 1980. Pengajaran Matematika Modern Untuk Orangtua, Murid, Guru dan SPG. Bandung: Tarsito.

Ngalimun. 2013. Strategi dan Model Pembelajaran. Yogyakarta: Aswaja Pressindo

Abidin, Yunus. (2016). Desain Sistem Pembelajaran Dalam Konteks Kurikulum 2013. Bandung: PT Refika Aditama.

Ridwan Abdullah Sani, Pembelajaran Saintifik untuk Implementasi Kurikulum 2013, (Jakarta: Bumi Aksara, 2014)

Ennis, R. H (1996). Critical Thinking. USA: Prentice Hall, Inc

Agus Suprijono. 2013. Cooperatif Learning Teori \& Aplikasi Paikem. Yogyakarta: Pustaka Pelajar

Sugiyono. 2012. Metode Penelitian Pendidikan Pendekatan Kuantitatif, Kualitatif, dan R\&D. Bandung: Alfabeta.

Suharsimi Arikunto. 2010. Prosedur Penelitian Suatu Pendekatan Praktik. Jakarta: Rineka Cipta.

Suharsimi Arikunto, dkk. 2014. Penelitian Tindakan Kelas. Jakarta: Bumi Aksara.

Ngalimun. 2013. Strategi dan Model Pembelajaran. Yogyakarta: Aswaja Pressindo

Komalasari, Kokom. 2013. Pembelajaran Kontekstul : Konsep dan Aplikasi. Bandung : PT Refika Adiatama 